\title{
先行自治体による公共施設再編計画の構成と内容に関する考察 DISCUSSION OF STRUCTURE AND CONTENT OF EARLY ADOPTING MUNICIPALITIES’ PUBLIC FACILITY REORGANIZATION PLANS
}

\author{
西野辰 哉* \\ Tatsuya NISHINO
}

\begin{abstract}
The reorganization of public facilities owned by Japan's municipalities is becoming a major issue. The purpose of this study is to understand the state of the establishment of public facility reorganization plans by municipalities nationwide, extract precedent examples of reorganization plans already established, and compare and discuss their structures and the criteria used to formulate the plans. The method of investigation was gathering documents and materials, which are related to reorganization plans of public facilities, from the websites of municipalities.
\end{abstract}

Keywords : Municipality, Public Facility, Reorganization, Structure, Content 自治体, 公共施設, 再編, 構成, 内容

\section{1. 研究の背景と目的、位置づけ}

我が国では 1960 年代の人口増加・高度経済成長期に多くの公共 施設の建設が行われたが、現在、それらが一斉に老朽化している。 また平成の市町村合併により類似施設が近隣に複数あるという自治 体もある。さらに公共施設の維持・修繥・建替えを行うには莫大な 費用がかかるが、人口減少を背景と寸る税収減により、その費用の 捻出が困難となっている。すなわち、我が国の自治体にとっては所 有する公共施設の量的削減を含めた再編が大きな課題となってい る。国もこれらの状況を看過していない。2014 年 4 月には総務省が 全国の地方公共団体に対して「公共施設等総合管理計画」の策定を 要請した ${ }^{1}$ 。これにより今後、自治体による公共施設の再編計画策 定が進むことが予測される。しかるに成長期における施設増量計画 とは異なり、施設総量の削減を含めた公共施設の再編計画は自治体 がこれまで策定したことのない類のものであり手探り状態にある。

そこで、本研究の目的は、全国の自治体における公共施設の再編 計画の策定状況を把握し、既に再編計画を策定した先行例を抽出し て、その構成と検討項目の策定方法に関する比較考察を行うことで ある。公共施設の再編計画を策定する際の手順や構成内容を体系的 に把握することにより、今後の再編計画策定に資寸ることに本研究 の意義があると考える。
なお、公共施設は、本来、建築物のみならず、道路、橋りょう、 上下水道などのインフラや、ゴミ焼却場、消防、斎場などのプラン トなども含むが、本稿では建築物のみを扱う。

公共施設再編に関する既往研究は施設計画系とマネジメント系の ものに大別される。前者では主に施設種別に再編が扱われるものが 大半であるが、本研究に近いのは自治体全体の視点から公共施設全 般を横断的に扱うものである。例えば、萩原・廣田ら（2013）は習 志野市を対象として公共施設保有量から施設別稼働率、老朽化度、 施設圈域、人口推移に関するベンチマークを作成し、公共施設整備 の現状を把握する方法の有効性を検証している ${ }^{2)}$ 。さらに畑・廣田 ら（2014）は同市内の学校施設に社会教育機能を複合し地域拠点化 する再編条件についてケーススタディを行っている3)。この中では 現状把握の後、施設配置、規模、整備時期に関する再編条件を設定 して、再編計画モデルプランを作成し、拠点性、近接性、経済性、 調整余地などの観点からその評価を行っている。また伊丹ら (2011) は豊中市の所有する公共施設の用途変更を含む使いこなしによる再 編状況を明らかにしている ${ }^{4)}$ 。本研究の先行例として両市も抽出し ているが、その再編手法について他自治体と比較する点において差 異化される。さらに友清ら（2008）は人口減少と市町村合併に伴う コミュニティ施設再編のための指標を「地理的状況」・「人」・財政」・
* 金沢大学理工研究域環境デザイン学系 准教授 $\cdot$ 博士 (工学)
Assoc. Prof., School of Environmental Design, College of Science and Engineering Kanazawa University, Dr. Eng. 
「施設」の 4 つに大別し、その課題を整理している ${ }^{5,6)}$ 。これらの既 往研究では個々の評価や指標、条件は抽出されているものの、それ らを統合した公共施設再編の手順として示されていない。

一方、マネジメント系、すなわちファシリティマネジメント (FM) の視点からのアプローチも見逃せない。例えば、まず山本・吉田 （2005）は全国の公共施設のストック量とその地域的特徴の実態を 明らかにしている7 ${ }^{7)}$ 。公共施設の維持保全コストについては、例えば、 山下・吉田ら（2008）が庁舎施設を対象としてそのあり方を検討し ている ${ }^{8)}$ 。また李・小松（2008）は地方自治体の公共施設の運営管 理状況をエネルギー消費量等の観点から明らかにしている9)。以上 は FM 分野での膨大な研究蓄積の数例に過ぎないが、一方で $\mathrm{FM}$ 的ア プローチの限界も指摘されている。例えば、山本 (2011) は「「企業・ 団体等が組織活動のために施設とその環境を総合的に企画、管理、 活用する経営活動」と定義されているFMでは、所有している建物 についての最適な状態 (コスト最小、効果最大) としての考えであり、 所有の有無についての判断には限界がある。」と指摘する ${ }^{10)}$ 。つま り所有の有無の検討も含めた施設全般の再編計画策定という枠組み を構築しうる点において FM 的な視点と差異化される。

\section{2. 研究の方法}

\section{2-1. 用語の定義}

公共施設の再編計画の名称と記載内容は各自治体によってまちま ちである。そこで本研究では以下のように定義する。

施設白書 : 現有施設の状況を整理したもの

再編方針：再編の全体方針（指針）を示したもの

再編基本計画 : 施設種別や地域毎の再編全体計画を示したもの

再編実施計画 : 具体的な再編の取り組み内容や個別施設の再編計

画を示したもの

例えば名称が「○○市公共施設再編計画」となっていても記載内 容が再編の方針しか示していなければ「再編方針」として扱う。そ して、再編方針、再編基本計画、再編実施計画の 3 つを総称して再 編計画とする。

\section{2-2. 研究の構成}

本研究の構成は次の通りである。まず第 3 章では全国の自治体に よる公共施設の再編計画策定の進捗状況を把握し（3-1)、先行例を 抽出する (3-2)。次に第 4 章では総務省による「公共施設等総合管 理計画策定要請」の項目の整理分類を試みた後、先行例について同 計画に記載すべき事項等の記載の有無を確認する。さらに同要請の 課題について検討する。そして第 5 章以降ではそれらの課題点につ いて明らかにすべく、先行例をもとに再編計画の構成内容について 比較考察する。第 5 章では先行例の再編計画を構成内容によって類 型化し、その課題と理想型について検討する。第 6 章では総務省に よる検討要望項目等の設定方法について比較考察する。具体的には、 1）行政サービス水準の評価方法、2）削減目標数值の設定方法、3) 再配置の地域単位の設定方法について比較考察する。最後に第 7 章 では再編計画フローのモデルを提示する。

\section{2-3. 調査と分析の方法}

本研究の対象は全国で 1,744（2013 年 9 月時点）の自治体の作成 した公共施設の再編計画である。調查方法は文献資料調查による。 まず公共施設の再編方針や再編計画にかかる資料を各自治体ホーム
ページからダウンロードするなどして蒐集した。また第 4 章の考察 のための総務省による公共施設等総合管理計画策定要請は同省ホー ムページから入手した。これらの資料をもとに全国の自治体の公共 施設の再編計画策定の進捗状況を把握し、再編計画を策定済みの自 治体の中から先行例を抽出した。その方法については第 3 章にて述 べる。抽出した先行例をもとに第 4 章以降の考察を行った。

\section{3. 全国自治体の公共施設の再編計画策定の進捗状況と先行例の抽出} 本章では全国の自治体による公共施設の再編計画策定の進捗状況 を把握し、先行例を抽出する。

\section{3-1. 全国の自治体による再編計画策定の進捗状況注1)}

図 1 は 2013 年 9 月時点における全国自治体の公共施設再編計画 策定の進捗状況を示す。最も多かったのが、再編計画や施設白書 がホームページで存在を確認できない自治体で $86.9 \%$ (1, 517 力所) であった。一方、再編計画を既に策定済の自治体は 4. 0 \% (70 力所)、 施設白書の夕策定済の自治体は 3.5\%（61 カ所）みられた。これら から公共施設の再編計画策定はあまり進んでいないことがわかる。

\section{3-2. 先行例の抽出}

次に再編計画を策定済の 70 自治体について細分類を行った（表 1)。2013 年 9 月調查当時、「実施方針又は実施計画があるが、再編 実施計画を策定中又は策定予定」の自治体が 31 力所あったため、 これらについて追跡調查を行い（2014.7)、その結果を交えて分類 した。そして、再編方針、再編基本計画、再編実施計画を策定済の 13 自治体、再編方針と再編基本計画を策定済の 7 自治体、再編方針 と実施計画を策定済の 10 自治体の合計 30 自治体を先行例として抽 出した ${ }^{11 \sim 40)}$ (表 2)。

図 2 に先行自治体の総人口と 1 万人あたりの公共施設数の関係を 示す。また図 3 に総人口と一人あたりの延床面積の関係を示す。記 載のあった自治体の一人あたりの延床面積の平均值は $3.55 \mathrm{~m}^{2}$ であっ

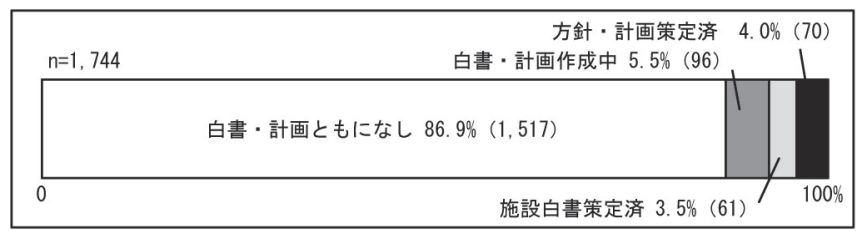

図 1 全国自治体の公共施設再編計画策定の進捗状況（2013.9）

表 12013.9 時点で再編計画策定済の自治体の修正分類(2014. 7 時点)

\begin{tabular}{|l|c|}
\hline \multicolumn{1}{|c|}{ 再編計画策定の進捗状況 } & 自治体数 \\
\hline 再編方針をもとに又は他計画と連携して再編実施 & 6 \\
\hline 再編方針、再編基本計画、再編実施計画を策定済 & 13 \\
再編方針、再編基本計画を策定済 & 7 \\
\hline 再編方針、再編実施計画を策定済 & 10 \\
\hline 再編方針のみ策定済 & 32 \\
\hline 再編実施計画のみ策定済 & 2 \\
\hline \multicolumn{1}{|c|}{ 合計 } & 70 \\
\hline
\end{tabular}

\section{表 2 先行例として抽出した 30 自治体}

再編方針、再編基本計画、再編実施計画を策定済 13

さいたま市、ふじみ野市、秦野市、浜松市、吳市、西東京市、飯塚市、玉名市、 三豊市、宮代町、清洲市、習志野市、坂井市 再編方針、再編基本計画を策定済

豊中市、上越市、滝川市、長浜市、稲沢市、川崎市、板橋区 再編方針、再編実施計画を策定済 10

寝屋川市、北名古屋市、狛江市、京丹後市、南砺市、対馬市、鎌ヶ谷市、美馬市、 白山市、能勢町 
た。これは東洋大学算出による全国平均值 $3.42 \mathrm{~m}^{2}$ とほぼ同じであ

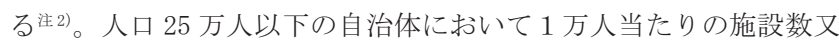
は一人当たりの延床面積が他に比べて多いものが散見される。

\section{4. 公共施設等総合管理計画策定要請の項目と課題に関する考察}

本章では 2014 年 4 月総務省から出された公共施設等総合管理計 画策定要請の項目と課題について考察する。同要請は総合管理計画 を策定する際に「記載すべき事項」と「留意事項」に分かれている(表 3)。第一の「記載すべき事項」は「検討を行い、その検討結果を総 合管理計画に記載することが適当」とされている。また第二の「留 意事項」は「検討寸ることが適当」とされている。

同要請での「記載すべき事項」と「留意事項」は 7 カテゴリに類 型可能であると思われる（表 4)。さらにそれらは、現状と将来に関 寸る認識（11(2)）、公共施設の総合的な管理実施の方針 (3)(4))、検 討すべき項目や手法 (5) (6) 、計画手続き（7)）の４つに大別可能 であると思われる。つまり、同要請の内容は、まず公共施設に関連 する現状を認識し、再編の基本方針を策定し、庁内体制を整えるこ とを要請している。一方で個別施設についての具体的評価や再編計 画については、別途「インフラ長寿命化基本計画」において策定が 期待されており、これを参考にするようにと述べるに留まっている。

同要請の各項目について、先行 30 例での記載の有無を記載率（記 載のあった自治体数 / 母数 30）でみる（表 3 右）。なお先行 30 例に おいて同要請の全項目を網羅したものはなかった。記載率をみると、 公共施設等の状況、計画期間、現状や課題に関する基本認識、施設 類型ごとの基本方針、行政サービス水準の検討、公共施設等の実態

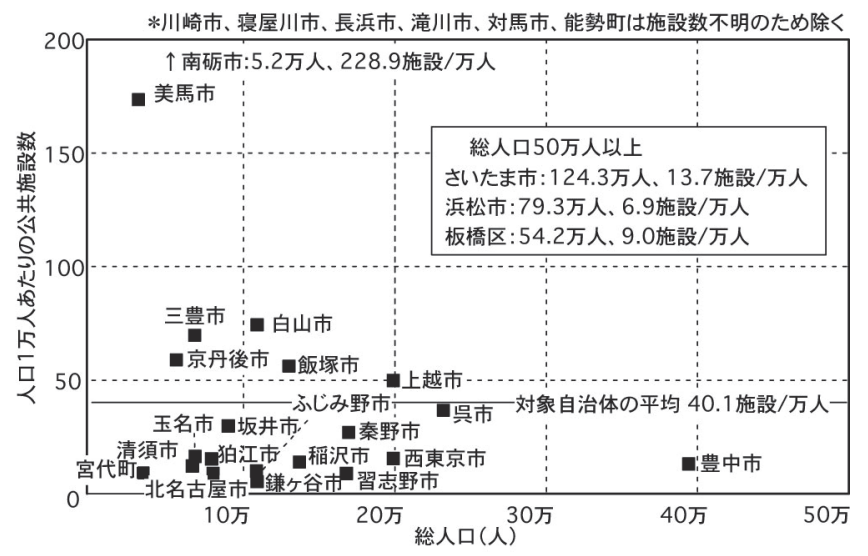

図 2 先行自治体の総人口と 1 万人あたりの施設数

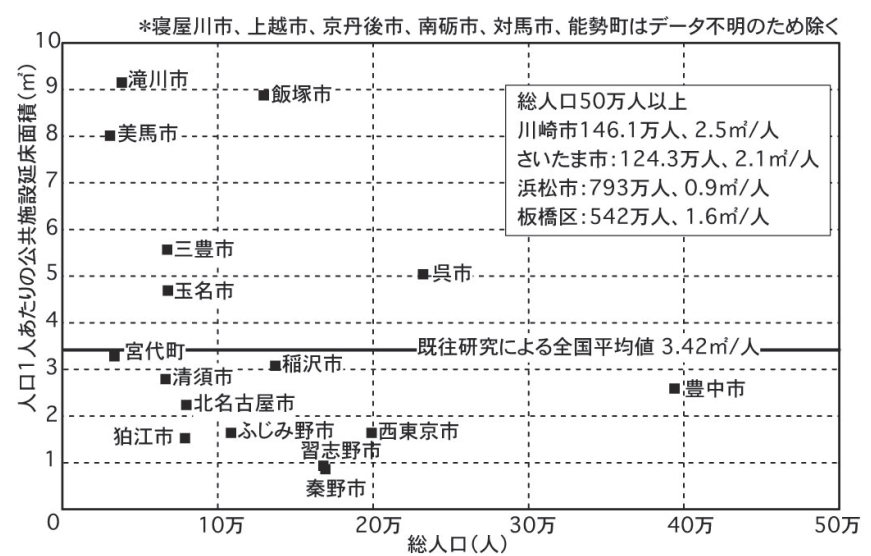

図 3 先行自治体の総人口と一人当たりの延床面積
把握及び総合管理計画の策定・見直しについては高い。しかし、公 共施設等の管理に関する基本認識の点検・診断の実施方針、安全確 保の実施方針、耐震化の実施方針についての記載率はかなり低い。 また数值目標設定や市区町村域を超えた広域的な検討等についても かなり低い。

但し、これらの項目を全て記載したとしても、これによって実行 可能な公共施設の再編計画が策定できるかについては疑問が残る。 少なくとも次の項目が課題として挙げられる。

・全体の検討手順が示されていない

・行政サービス水準の評価と検討の方法が示されていない

・数值目標の設定方法が示されていない

従って、同要請を満たす公共施設再編の実施計画の模範例は先行 例の記載内容を精查して組み合わせる他ないであるう。さらに公共 施設の再編や再配置は「選択と集中」を旨とする都市計画政策注3) との連関があってしかるべきであると思われるが、総務省要請には これに関する記載がない。

表 3 先行事例 30 自治体の総務省要請項目と先行自治体の記載率 \begin{tabular}{|l|l} 
総務省要請の項目 & 記載率 \\
\hline
\end{tabular} 第一 総合管理計画に記載すべき事項

公共施設等の現況及び将来の見通し

（1）老朽化の状況や利用状況をはじめとした公共施設等の状況 0.80

（2）総人口や年代別人口についての今後の見通し（30 年程度が 0.73 望ましい)

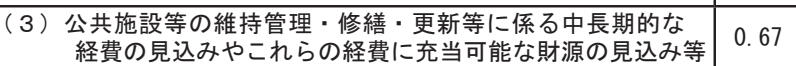

二 公共施設等の総合的かつ計画的な管理に関する基本的な方針

\begin{tabular}{|c|c|}
\hline & \\
\hline (2) 全庁的な取組体制にの構築及び情報管理・共有方策 & 0.43 \\
\hline （3）現状や課題に関する基本認識 & 0.90 \\
\hline (4) 公共施設等の管理に関する基本認識 & - \\
\hline (1)点検・診断等の実施方針 & 0.13 \\
\hline (2)維持管理・補修・更新等の実施方針 & 0.40 \\
\hline (3)安全確保の実施方針 & 0.23 \\
\hline (4)耐震化の実施方針 & 0.23 \\
\hline (5)長寿命化の実施方針 & 0.50 \\
\hline (6)統合や廃止の推進方針 & 0.77 \\
\hline 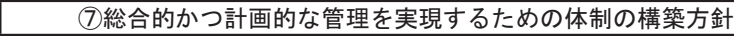 & 0.47 \\
\hline (5) フォローアップの方針 & 0.57 \\
\hline 三 施設類型ごとの基本方針 & 0.87 \\
\hline 第二＼cjkstart総合管理計画策定にあたっての留意事項 & \\
\hline 一＼cjkstart行政サービス水準等の検討 & 1.00 \\
\hline 二 公共施設等の実態把握及び総合管理計画の策定・見直し & 1.00 \\
\hline 三 議会や住民との情報共有 & 0.63 \\
\hline $\begin{array}{ll}\text { 四 } & \text { 数值目標の設定 } \\
\end{array}$ & 0.17 \\
\hline 五 PPP/PFI の活用について & 0.53 \\
\hline 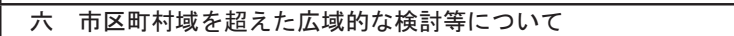 & 0.13 \\
\hline 合併団体等の取組について & 0.60 \\
\hline
\end{tabular}

表 4 公共施設等総合管理計画策定要請項目のカテゴリ分類

\begin{tabular}{|c|c|c|}
\hline \multirow{3}{*}{$\begin{array}{l}\text { 大カデゴリ } \\
\text { 現 状 と将寽に関す } \\
\text { る認識 }\end{array}$} & カテゴリ & 要請項目 \\
\hline & $\begin{array}{l}\text { 1)現況と将来推計 } \\
※\end{array}$ & \begin{tabular}{|l} 
公共施設の状況、総人口等の見通し、公共施 \\
設等の維持管理修繥更新経費、財源の見込
\end{tabular} \\
\hline & $\begin{array}{l}\text { (2)現状や課題に } \\
\text { 対する基本認識※ }\end{array}$ & 現状や課題に対する基本認識 \\
\hline \multirow{2}{*}{$\begin{array}{l}\text { 公共施設 } \\
\text { の総合的 } \\
\text { な管理実 }\end{array}$} & (3)実施方針※ & $\begin{array}{l}\text { 維持管理·補修·更新、耐震化、長寿命化、統合· } \\
\text { 廃止 }\end{array}$ \\
\hline & $\begin{array}{l}\text { (4)施設類型毎の } \\
\text { 方針 }\end{array}$ & 施設類型毎の方針 \\
\hline \multirow{2}{*}{$\begin{array}{l}\text { 検討すべ } \\
\text { 項目や } \\
\text { 手法 }\end{array}$} & (5)検討要望項目 & 行政サービス水準、数值目標 \\
\hline & \begin{tabular}{|l} 
6)取り入れるべき \\
効率化手法
\end{tabular} & PPP/PFI、広域連携 \\
\hline $\begin{array}{l}\text { 計 画 手続 } \\
\text { き }\end{array}$ & 7)計画手続き & $\begin{array}{l}\text { 期間※、体制※、公共施設等の実態把握及 } \\
\text { び総合管理計画の策定·見直し、議会·住民 } \\
\text { との情報共有、合併団体での取組み }\end{array}$ \\
\hline
\end{tabular}




\section{5. 先行例の構成内容の類型化に関する考察}

本章以降では総務省要請の課題点について明らかにす心゙く、先行 30 例をもとに比較考察を行う。

まず 5 章では再編計画の構成内容について比較考察する。先行 30 例の再編計画の構成内容は大カテゴリ 3 類型、小カテゴリ 9 類型に 分類可能である (表 5)。このうち大カテゴリ A 型は施設種別に現有 施設の再編方針検討結果を提示するもの (ボトムアップ型)、B 型は 全市的検討から削減目標量を明示するもの（トップダウン型）、C 型 は A・B 型の統合型とした。なお B 型については理論上ありうるも のの、今回は施設種別や施設個別の検討まで進んでいるものを先行 例として抽出したため、その中にはなかった。

以下にボトムアップ型と統合型の再編計画の手順を例示する。

\section{5-1. 施設種別の現有施設検討によるボトムアップ型（A 型）}

ボトムアップ型（A 型）は施設種別に現有施設の再編方針検討結 果を提示するものである。

まず $\mathrm{A} 1$ 型は全市的な基本方針にふれた上で施設種別の検討が中 心に行われ、それらをとりまとめた形となっている。

次に A2 型は基本的に $\mathrm{A} 1$ 型と同じであるが、施設個別の再編方針 まで明示している。

そして $\mathrm{A} 3$ 型も基本は $\mathrm{A} 1$ 型と同じであるが、既存施設の客観的評 価視点を明示しているものである。特に再編計画策定の手順まで緻 密に示している例として、豊中市の公共施設再編の手順を図 4、5 に示す。まず施設管理部局が市有施設のデータベース（ストック情 報、コスト情報、サービス情報、地域情報）をもとに評価指標を 用いて個別施設の評価を行い、「市有施設有効活用調整シート」と してまとめる（図 4 (1)(2)、図 5 (1)〜 (4))。この際、施設管理者によ る評価も交え（図 5 (3)）、さらに市全体の施策の方向性、分野別の 施設配置のあり方、部局全体の戦略をふまえて評価する（図 5 (4))。 次に資産活用担当部局が各施設所管部局が作成した「市有施設有効 活用調整シート」を集約して課題抽出を行い、第三者機関の意見も 交えて、全市的な全体最適の視点から市有施設の有効活用方策を打 ち出した「市有施設有効活用状況」を作成する。この中で、毎年度、 重点的に管理運営・事業を見直寸施設（以下、特定施設と寸る）の 候補を選定する。特定施設については、廃止・複合化・建替・改修・ 転用などの「有効活用方策案」を検討し、政策会議で確定した後、有 効活用アクションプラン」を検討して重点的に有効活用を図る。そ れ以外の施設は LCC の考えに基づく計画的保全を実施する。

さらに $\mathrm{A} 4$ 型は $\mathrm{A} 2$ 型に加えて客観的評価視点も明示しているもの で、該当するのは対馬市のみであった。

最後に $\mathrm{A} 5$ 型は $\mathrm{A} 1$ 型に加えて地域別検討結果も提示しているもの である。

\section{5-2. 施設種別検討と全市的検討をあわせもつ統合型（C 型）}

次に C 型は施設種別の現有施設の検討に加えて全市的検討から削 減目標值を設定した統合型である。施設種別の再編方針検討結果を 示寸か、施設個別の再編方針検討結果も示寸か、さらに客観的評価 視点も明示しているかなどでC1、C2、C3 に細分類した。

ここでは再編手順を明示している例として C2 型の秦野市を取り 上げる。秦野市では 2009 年 10 月に「公共施設白書」を作成した上で、 2011 年 3 月に「公共施設再配置計画」を策定した。その中では公共 施設再編の大まかな流れが以下のように記されている。まず公共施
表 5 再編計画の構成内容の細分類

\begin{tabular}{|c|c|c|c|}
\hline \multicolumn{2}{|c|}{ 型 } & 内容 & 先行例 \\
\hline \multirow{5}{*}{ A } & $\mathrm{A} 1$ & 施設種別の再編方針検討結果を提示 & $\begin{array}{l}\text { 吳市、飯塚市、ふじみの } \\
\text { 市、狛江市、稲沢市、寝 } \\
\text { 屋川市、能勢町 }\end{array}$ \\
\hline & A2 & A1 かつ施設個別の再編方針結果も提示 & $\begin{array}{l}\text { 浜松市、北名古屋市、 } \\
\text { 美馬市、清洲市 }\end{array}$ \\
\hline & A3 & A1 かつ客観的評価視点を明示 & $\begin{array}{l}\text { 川崎市、豊中市、南砺市、 } \\
\text { 京丹後市、白山市、上越 } \\
\text { 市、鎌ヶ谷市、長浜市、 } \\
\text { 坂井市 }\end{array}$ \\
\hline & A4 & A2 かつ客観的評価視点を明示 & 対馬市 \\
\hline & A5 & A1 かつ地区別検討結果も提示 & $\begin{array}{l}\text { 西東京市、習志野市、板 } \\
\text { 橋区、滝川市、宮代町 }\end{array}$ \\
\hline$B$ & B1 & 全市的検討から削減目標値を明示 & 該当なし \\
\hline \multirow{3}{*}{ C } & $\mathrm{C1}$ & $\mathrm{A} 1$ かつ B1 & さいたま市、玉名市 \\
\hline & $\mathrm{C} 2$ & $\mathrm{~A} 2$ かつ A5 かつ B1 & 秦野市 \\
\hline & $\mathrm{C3}$ & A3 かつ A5 かつ B1 & 三豊市 \\
\hline
\end{tabular}

設の総量維持は不可能であるという前提にたち、4つの方針を決定 した（図 6)。そして「公共施設再配置計画」では各コミュニティ拠 点とエリアを定めて、そのエリア毎に個別の地域施設の再編方針を 示す。そして、2011 年〜 2020 年を第 1 期基本計画期間と定め、前 期 5 年間には、 4 つのシンボル事業（義務教育施設と地域施設の複 合化、公共的機関のネットワーク活用、小規模地域施設の移譲と開 放、公民連携によるサービス拡充）を行い、後期 5 年間も含め、10 年間で更新面積 $1,340 \mathrm{~m}^{2}$ と管理運営費用等 57 億円の削減を計画し ている。また第 1 期基本計画及び前期実行プランには施設別に再配 置の方向性と計画内容が記載されている。

秦野市の計画の大きな特徵は、自治体運営上、必要最小限の重要 機能、寸なわち義務教育、子育て支援、行政事務スペースを最優先 に機能維持更新する施設として決定し、全市的な施設更新費用推計 等をもとに施設総量の削減目標を設定している点である。この点が トップダウン型に該当する部分である。さらに基本計画及び前期実 行プランに施設種別の検討も記載されているので統合型とした。

別例として C3 型の三豊市の再編計画を示す（図 7)。三豊市の再 配置に関する方針は、秦野市を参照し、方針 1 : 基本方針の策定、 方針 2 : 施設更新優先度の設定、方針 3 : 削減目標量の設定までは、 ほぼ同じである。しかし、方針 4 : 再配置の見直しの進め方として、 個々の施設毎の評価に言及寸る。その流れは、一次評価（個別の施 設の客観的評価による現状把握)、二次評価（施設のあり方の明確 化）、三次評価（課題施設の詳細調査の実施）となっており、これ をもとに「公的関与の必要性」について検証する。つまり、方針 4 の部分がボトムアップ的プロセスにあたり、そこに秦野市のトップ ダウン的プロセス部分の方針 1 ～ 3 をかぶせた形となっている。

\section{5-3. 再編計画の理想型と各型の課題点}

総務省要請においては「施設の現況」は記載すべき事項、「数值 目標の設定」は留意事項として求められているため、再編計画の理 想はトップダウン型とボトムアップ型の統合型と考えられる。

そこで各型の課題点について考察する。まずボトムアップ型は現 有施設の状況を反映しうるものの自治体の財政面から将来も公共施 設群を維持管理可能かという検討視点が欠けている。一方、トップ ダウン型や統合型において施設の削減目標值は個別施設の現況評価 に関係なく市全体の財政と現況施設の維持管理コストの面から設定 される。そのため施設の現況や評価と削減目標值をどうすりあわせ ていくかが大きな課題になると考えられる。そこで両者のすりあわ 
(1)施設所管部局が市有施設の現状に関する情報から作成した評価指標によ
る評価と施設管理者による評価によって市有施設の現状を評価する。

(2)施設所管部局は(1)の評価に加え、事業等の戦略的たな卸し（注）の成果 や行政評価などの結果、総合計画の実施計画などをふまえた施策の方向 性からの検討と、地域の特性やサービス圏域ならみた施設配置状況をふ まえ、「市有施設有効活用調整シート」の作成を行う。

(3)資産活用担当部局は、(2)で作成した各部局の「市有施設有効活用調整シー 卜」を集約して課題の抽出を行い、全市的な視点から市有施設の有効活 用方策を打ち出した「市有施設有効活用状況」を作成する。

(4)「市有施設有効活用状況」から、毎年度、重点的に管理運営・事業を見 直す施設 (以下、特定施設とする) の候補を選定する。特定施設候補に ついては中期財政収支見積に基づく一般財源をふまえたシミュレーショ ンなどを行い、廃止・複合化・建替・改修・転用等の「有効活用方策案」 を検討する。

(5)政策会議等を経て特定施設を確定する。特定施設については「有効活用 アクションプラン」を策定し、重点的に有効活用を図る。特定施設以外 の施設は LCC の考え方に基づく計画的保全を実施する。

図 4 豊中市の市有施設の有効活用にむけての評価の手順

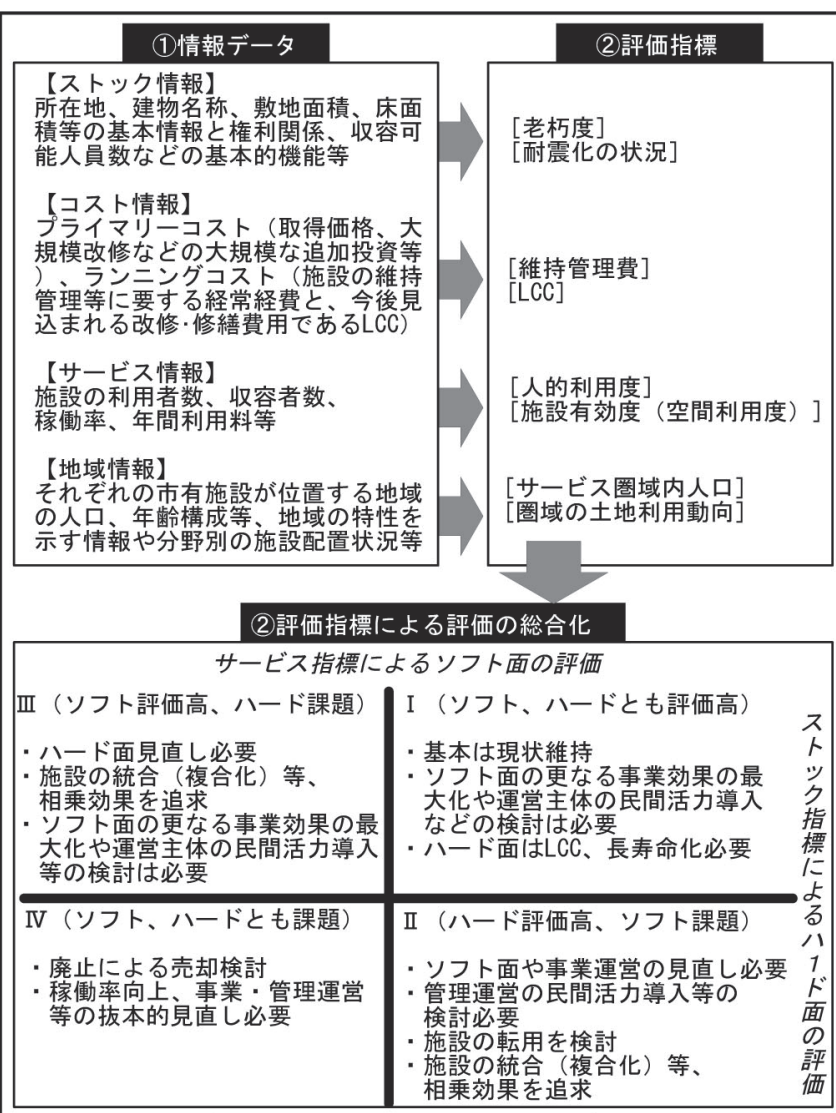

(3)施設管理者による評価

市民ニーズ、利用者満足度、政策・施策への貢献度や施設の効果 など定性的な評価

(4)施設所管部局による総合評価

市全体の施策の方向性、分野別の施設配置のあり方、部局全体 の戦略をふまえてそれぞれの施設を評価

図 5 豊中市の「市有施設有効活用調整シート」の作成手順

せ方について事例をみる。秦野市の場合、再編方針 2 の更新の優先 度にあわせて削減目標量を学校とその他施設に分けた上で学校を重 視するように傾斜配分する。次に「シュミレーション結果に近づけ るように実際の建物の耐用年数到来時に優先順位に従いながら残す 残さないを決定し計算した数值」注 4 )を最終的削減目標量として設 定した。つまり削減目標量は現況施設の再編方針も含めて緻密に設 定された。一方、三豊市も全く同様に削減目標量を学校とその他施
方針 1 基本方針

1)原則として新規のハコモノは建設しない

(2)今あるハコモノも大幅圧縮

(3)統廃合施設の用地は売却・賃貸し更新経費に

(4)ハコモノは一元的マネジメントを行う

方針 2 更新の優先度

機能維持が最優先されるのは義務教育、子育て支援、行政事務

方針 3 削減の数値目標

方針 4 再配置の視点

(1)将来を見据えた施設配置を進める

(2)市民の力、地域のカによる再配置を進める

(3)多機能化などによるサービス向上と戦略的経営を進める

(4)効率的・効果的な管理運営を進める

(5)計画的な施設整備を進める

図 6 秦野市の公共施設再配置計画・第一ステージの方針

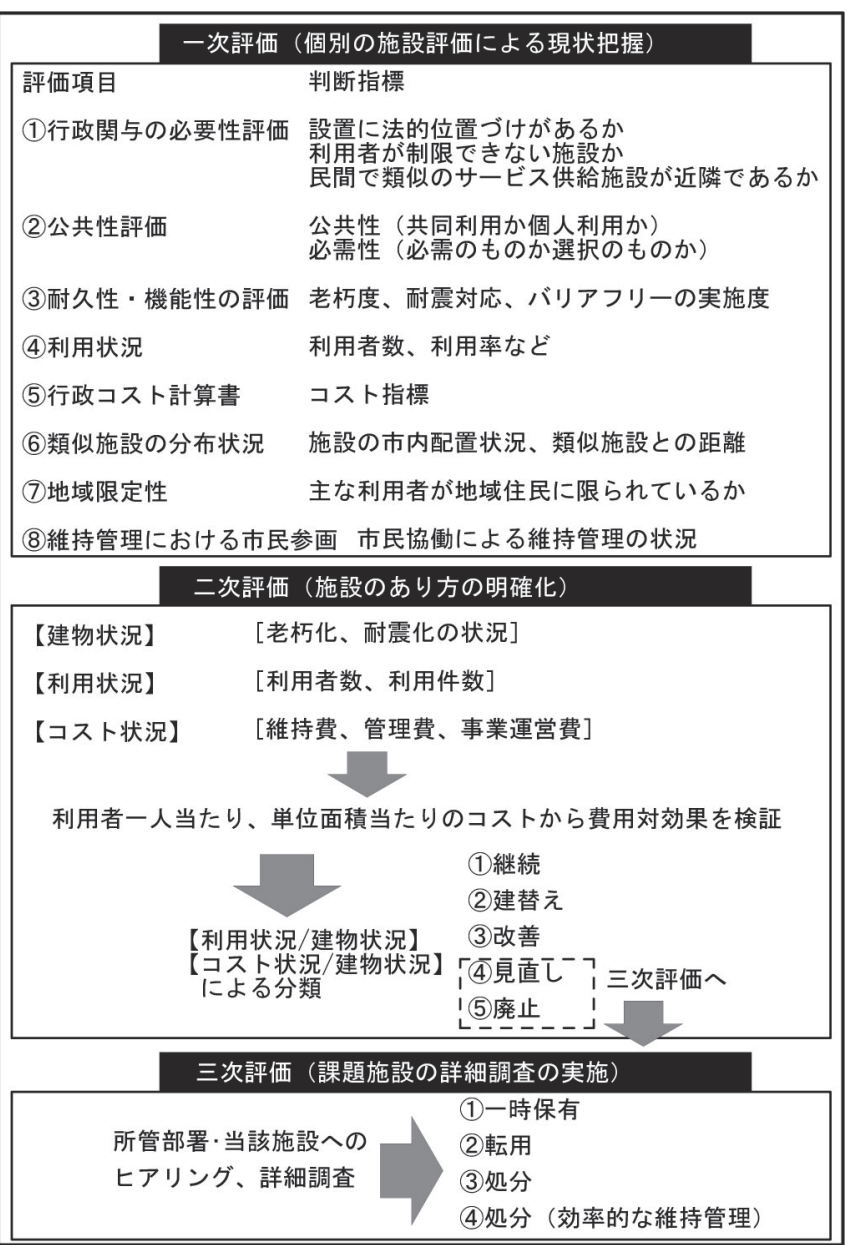

図 7 三豊市の既存施設の評価の流れと項目

設に傾斜配分している。三豊市の場合、ボトムアップ的な既存施設 の現況評価プロセスが明示されているがゆえに、トップダウン的に 設定された削減目標量との整合性がとられているのか疑問である。 現実にこれらの整合性をとる方法としては再編実施計画において 個々の既存施設の更新時期と削減延床面積を勘案しながら定期的に 調整を繰り返していくことになるものと推測される。

以上、総務省要請により削減目標量設定が必須となるため再編計 画手続きの理想はトップダウン型とボトムアップ型の統合型と考え られる。その際、削減目標量と既存施設の現況評価とのすりあわせ が課題となる。削減目標量は現況施設の再編方針も含めて緻密に設 定するか、再編実施計画で定期的調整を繰り返すものと考えられる。 


\section{6. 検討要望項目等の設定方法に関する考察}

本章では総務省要請で検討要望項目とされる行政サービス水準の 評価方法と削減目標量の設定方法、そして同要請で久落している都 市計画的視点から再配置の地域単位の設定方法について先行例を比 較考察する。

\section{6-1. 行政サービス水準の評価方法}

1) 既存施設の評価視点

行政サービス水準の評価方法を比較するために、まず先行例にお ける既存施設の評価視点を整理する。表 6 は既存施設の客観的評価 視点を提示している 11 自治体（表 5 中 A3, A4, C3）の評価視点から カテゴリを抽出したものである。これにより、既存施設の評価視点 として、公共性、建物、コスト、サービス、施設配置、その他の 6 大カテゴリに分類できたことがわかる。

\section{2) 行政サービス水準の検討}

では総務省要請にある「行政サービス水準の検討」はどのように 行われるのだろうか。同要請では「(前略) 当該団体としてあるべき 行政サービス水準を検討することが望ましい。その上で、個別の公 共施設等において提供しているサービスの必要性について検討する に際しては、当該サービスが公共施設等を維持しなければ提供不可 能なものであるか（民間代替可能性）など、公共施設等とサービス の関係について十分留意することが必要である」としている。

表 6 でサービスカテゴリの視点は、利用者数 (利用率)、利用者満 足度、稼働率である。しかし、利用者数（利用率）と稼働率は定量 的指標であるが適正水準を示寸判別值がなく、また利用者満足度は 定性的指標であるため、いずれも相対的評価しかできない。

これらの視点から、どのように行政サービス水準が評価されてい るのか、再編評価プロセスが明示されている豊中市の例をみる。同 市では、公共サービス評価は人的利用度（単位床面積当たりの利用 者数）と空間利用度（単位床面積あたりの稼働率）が指標とされ、 ストックやコストの評価と合わせて総合化される (図 5 (2)座標軸)。 そして、この座標軸の II 又はIVの象限に分類された施設はソフトや 事業運営の見直しが必要とされる。この際、ストック評価における $\mathrm{Y}$ 軸方向の正か負かは市内全施設の平均值を上回るか下回るかで決 まる。またサービス評価におけるX軸の正か負かは市内同種施設の 平均值を基準とする。さらに施設管理者による定性的な評価、具体 的には市民ニーズ、利用者満足度、政策・施策への貢献度、施設の 効果などの評価も加えられる (図 5 (3))。その後、施設所管部局によっ て総合評価される際に市の施策の方向性も加味される (図 5 (4)）。具 体的には、市の行財政構造改革本部による「事業等の戦略的たな卸 し」の結果をもとに施設種別の施設活用方針が明示されている。な お、これらの定性的評価に関する基準值は明示されておらず、所管 部局における総合評価も「大局的に判断する必要がある」としている。 以上、豊中市では、行政サービスは利用率や稼働率等の定量的指標と、 市民ニーズや満足度、市の施策への貢献度等の定性的指標も交えて 評価されている。そして定量的指標は市内の全施設又は同種施設の 平均值を判別值として用いている。一方、定性的指標には判別值が なく、総合評価で大局的に判断するとしている。

利用率や稼働率等の定量的指標の判別值を明示している他例をみ ると、白山市と坂井市が同種施設の平均值、鎌ヶ谷市が独自の基準 (一 日当たりの利用者数が 50 人以下）に対寸る該当するか否かとなって
いる。つまりサービス評価の定量的指標の判別值としては同種施設 平均值が大半となっている。しかし平均值は母集団の選び方によっ て異なる。また、あるべき水準と平均は必ずしも同義ではない。従っ てその適正水準值の設定が重要な検討課題として挙げられる。これ らに対して全国・都道府県別等を母集団とした施設種別の利用率や 稼働率等の定量的指標の平均値算出とその適正性に関する考察は今 後の課題としたい注5)。

\section{3）サービスの必要性の検討}

次に総務省要請の「サービスの必要性についての検討」という観 点については表 6 の公共性カテゴリが相当する。このカテゴリには、 設置根拠、設置目的とニーズの整合性、公共負担の適切性（民間代 替可能性）の 3 小カテゴリがある。これらはサービスの必要性の有 無或いは公共サービスとして提供すべきか否かを検討するものであ る。これらの検討項目がない自治体もみられたが、これらの項目の 検討によりサービスの廃止や民間移譲など公共施設数や面積の縮減 に直接的につながる判断が可能になると考えられる。

\section{4) 小まとめ}

本節をまとめると、まず既存施設の評価視点として、公共性、建 物、コスト、サービス、施設配置、その他の 6 類型がみられた。次 に総務省要請にある「行政サービス水準の検討」に関する評価項目 として、利用者数、稼働率等の定量的指標や、利用者満足度等の定 性的指標がみられた。定量的指標については平均值を判別值とする 例がみられたが、定性的指標には判別值がなく相対的評価とならざ るをえない。また、あるべき水準と平均は同義ではないので、少な くとも定量的指標についての適正水準值の提示は重要な検討課題と なる。また設置根拠、設置目的とニーズの整合性、公共負担の適切 性（民間代替可能性）の視点からの検討により、公共施設数や面積 の縮減に直接的につながる判断が可能になると考えられる。

\section{6-2. 削減目標値の設定方法}

次に削減目標值の設定方法について検討する。具体的な削減目標 值を掲げているのは、さいたま市、秦野市、三豊市、玉名市の 4 か 所であった。このうち、さいたま市は「今後 40 年間で $15 \%$ 程度の 縮減が必要」とするものの、その算出根拠は明示されていない。ま た三豊市は秦野市の方法を参照していることから、秦野市と玉名市 の方法について比較する。

\section{1) 秦野市}

まず秦野市では今後の施設更新等経費の不足見込額を試算してい る。建設費を 35 万円 $/ \mathrm{m}^{2}$ と仮定して今後 $10 〜 40$ 年でどれだけ更 新等経費が不足するかを算出した。そして現在の施設更新費用 2.5 億円 / 年が今後も続き施設更新量を $50 \%$ と仮定しても、20 年後に財 源不足となる試算となった。

そこで小中学校舎を耐用年数どおりに、その時期の児童生徒数に 応じて建替えることを優先し、いつまでにどれくらいの施設更新量 を削減すれば、削減施設分の管理運営費用で他の施設更新費用を賄 えるのかをシミュレーションした。計算期間は $2010 ２ 050$ 年まで の 40 年間、施設管理運営費は小中学校 8,547 円 / $\mathrm{m}^{2}$ 、その他施設 28, 379 円 / $\mathrm{m}^{2}$ と仮定した。その結果、更新量 $70.8 \%$ (29.2\%削減) と試算された。図 8 に秦野市の計算式を一般式化したものを示す。 秦野市では、10、20、30、40 年後の 4 期分を算出しているが、図 8 では 40 年後の施設更新費不足額と削減施設分の管理運営費削減費 
表 6 再編プロセスにおける既存施設の評価視点

\begin{tabular}{|c|c|c|c|c|c|c|c|c|c|c|c|c|}
\hline $\begin{array}{c}\text { 大 } \\
\text { カデブリ }\end{array}$ & $\begin{array}{l}\text { 小 } \\
\text { 功ゴリ }\end{array}$ & 川崎市 & 豊中市 & 上越市 & 三豊市 & 京丹後市 & 南砺市 & 坂井市 & 長浜市 & 鎌ヶ谷市 & 白山市 & 対馬市 \\
\hline \multirow{3}{*}{ 公共性 } & 設置根拠 & 市の施策的方針 & \begin{tabular}{|l|} 
政策・施策 \\
ヘの貢献 \\
度、施策の \\
方向性、部 \\
局の戦略 \\
\end{tabular} & & \begin{tabular}{|l} 
法的根拠の有 \\
無
\end{tabular} & & \begin{tabular}{|l} 
政策目標の実 \\
現度
\end{tabular} & & 法令制約の有無 & & & 設置根拠 \\
\hline & $\begin{array}{l}\text { 設置目的 } \\
\text { と二ーズ } \\
\text { の整合性 }\end{array}$ & & 市民ニーズ & & \begin{tabular}{|l} 
I 公共性評価 \\
(必需かどう \\
只共同利用 \\
か個人利用か)
\end{tabular} & 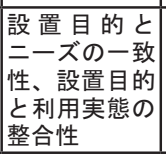 & & & \begin{tabular}{|l} 
設置目的と=ー \\
ズとの合致性
\end{tabular} & 市民二ー & & $\begin{array}{l}\text { 住民生活に } \\
\text { おいて又は } \\
\text { 将来的に不 } \\
\text { 可欠な施設 } \\
\text { か }\end{array}$ \\
\hline & $\begin{array}{l}\text { 公共負担 } \\
\text { の適 切 } \\
\text { 性(民間 } \\
\text { 代替可能 } \\
\text { 性) }\end{array}$ & & & $\begin{array}{l}\text { 代替施 } \\
\text { 設の有 } \\
\text { 無、公 } \\
\text { 費負担 } \\
\text { 額 }\end{array}$ & 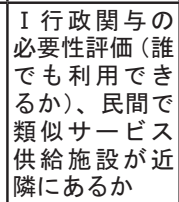 & \begin{tabular}{|l|} 
民間施設との \\
競合 \\
\end{tabular} & \begin{tabular}{|}
$\mid$ 代替施設や競 \\
合施設の有無
\end{tabular} & & \begin{tabular}{|l|} 
公共性の有無、 \\
受益者負担によ \\
る採算性 (市場 \\
原理導入の可否)
\end{tabular} & $\begin{array}{l}\text { 行政関与 } \\
\text { の妥 } \\
\text { 性、当代替 } \\
\text { 施設の有 } \\
\text { 無 }\end{array}$ & $\begin{array}{l}\text { 公費負 } \\
\text { 担 状 } \\
\text { 沿、費 } \\
\text { 用詨効 } \\
\text { 果 }\end{array}$ & $\begin{array}{l}\text { 民間を含め } \\
\text { た代 替施 } \\
\text { 設、民間に } \\
\text { よる運営が } \\
\text { 可能か }\end{array}$ \\
\hline \multirow{3}{*}{ 建物 } & 老朽化度 & 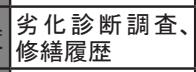 & 老朽度 & \begin{tabular}{|l} 
老朽化 \\
程度
\end{tabular} & $\begin{array}{l}\text { I 耐久性の評 } \\
\text { 価、II 老朽度 } \\
\end{array}$ & 施設劣化 & 安全性 & \begin{tabular}{|l|} 
老朽 化 \\
状況 \\
\end{tabular} & 老朽化 & 老朽化度 & 老朽度 & \\
\hline & \begin{tabular}{|l|} 
耐震化の \\
状況
\end{tabular} & 耐震調査 & \begin{tabular}{|l|} 
耐震化の状 \\
況
\end{tabular} & \begin{tabular}{|l} 
耐震強 \\
度
\end{tabular} & $\begin{array}{l}\text { II 耐震化の状 } \\
\text { 況 }\end{array}$ & & 安全性 & \begin{tabular}{|l|} 
耐震 化 \\
状況
\end{tabular} & & & 耐震性 & \\
\hline & \begin{tabular}{|l} 
バリアフ \\
リー性
\end{tabular} & $\begin{array}{l}\text { ユニバーサルデ } \\
\text { ザイン、バリア } \\
\text { フリー対応 }\end{array}$ & & & $\begin{array}{l}\text { I 機能性の評 } \\
\text { 価 (バリアフ } \\
\text { リー) }\end{array}$ & & $\begin{array}{l}\text { ユニバーサル } \\
\text { デザイン対策 }\end{array}$ & $\begin{array}{l}\text { バリア } \\
\text { フリー } \\
\text { 状況 }\end{array}$ & & & & \\
\hline \multirow{4}{*}{ コスト } & $\begin{array}{l}\text { 維持費· } \\
\text { 管理費· } \\
\text { 運営費 }\end{array}$ & $\begin{array}{l}\text { 維持管理費、運 } \\
\text { 党費、資産取得 } \\
\text { 費、市税に対す } \\
\text { る資産維持費の } \\
\text { 占める割合 }\end{array}$ & 維持管理費 & \begin{tabular}{|l} 
施設収 \\
支
\end{tabular} & \begin{tabular}{|l|} 
I 行政コスト \\
計算書、II 維 \\
持費、管理費、 \\
事業運営費
\end{tabular} & 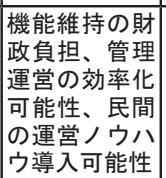 & & $\begin{array}{l}\text { 維 持管 } \\
\text { 理 費 状 } \\
\text { 況、運 } \\
\text { 営人員、 } \\
\text { 運営 体 } \\
\text { 制 }\end{array}$ & & $\begin{array}{l}\text { 管理運営 } \\
\text { 経費、土 } \\
\text { 地建物取 } \\
\text { 得費 }\end{array}$ & & \\
\hline & \begin{tabular}{|l} 
ライフサ \\
イクルコ
\end{tabular} & 省エネ機器の採 & ライフサイ & \begin{tabular}{|l} 
大規模 \\
修経
\end{tabular} & \multirow{2}{*}{\multicolumn{2}{|c|}{$\begin{array}{l}\text { 三豊市 } \\
\text { I : 一次評価項目 } \\
\text { II : 二次評価項目を示す }\end{array}$}} & \begin{tabular}{|l|} 
ライフサイク \\
ルコストから \\
みた効率性有
\end{tabular} & $\begin{array}{l}\text { 施設維 } \\
\text { 持 } コ \text { ス } \\
\vdash 、 \text { 減 }\end{array}$ & \begin{tabular}{|l|} 
\\
費用対効果から \\
大規模修絟や耐
\end{tabular} & & & \\
\hline & ス卜 & & クルコスト & |修繥 & & & \begin{tabular}{|l|} 
恔性、環境負 \\
何低減
\end{tabular} & \begin{tabular}{|l|} 
価償 却 \\
費
\end{tabular} & 震補強の有効性 & & & \\
\hline & \begin{tabular}{|l} 
資産評価 \\
額
\end{tabular} & $\begin{array}{l}\text { 不動産鑑定評価 } \\
\text { 額、固定資産評 } \\
\text { 価額、貸付料収 } \\
\text { 入額 }\end{array}$ & & & & & & & & & & \\
\hline \multirow{3}{*}{$\begin{array}{c}\text { サービ } \\
\text { ス }\end{array}$} & $\begin{array}{l}\text { 利用者数 } \\
\text { (利用率) }\end{array}$ & 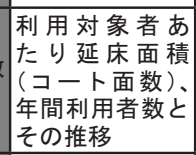 & $\begin{array}{l}\text { 人的利用度 } \\
\text { (単位床面 } \\
\text { 積当たりの } \\
\text { 利用者数) }\end{array}$ & $\begin{array}{l}\text { 利用者 } \\
\text { 数、利 } \\
\text { 用動向 } \\
\text { (変化) }\end{array}$ & $\begin{array}{l}\text { I 、I 利用者 } \\
\text { 数、利用件数 }\end{array}$ & 利用率 & 利用者数 & $\begin{array}{l}\text { 利 用 件 } \\
\text { 数、利 } \\
\text { 用人数 }\end{array}$ & & $\begin{array}{l}\text { 利 用 者 } \\
\text { 数、将来 } \\
\text { 利用者見 } \\
\text { 込み }\end{array}$ & $\begin{array}{l}\text { 利用者 } \\
\text { 数 }\end{array}$ & 利用率 \\
\hline & 満足度 & 利用者満足度 & \begin{tabular}{|l|}
$\begin{array}{l}\text { 利用者満足 } \\
\text { 度 }\end{array}$ \\
\end{tabular} & & & & 利用者満足度 & & \begin{tabular}{|l|} 
サービス向上可 \\
能性
\end{tabular} & & & \\
\hline & |稼働率 & $\begin{array}{l}\text { 機能別 ·室別コ } \\
\text { マ稼動率、低稼 } \\
\text { 動率の占める割 } \\
\text { 合 }\end{array}$ & \begin{tabular}{|l|} 
施設有効度 \\
(単位床面 \\
積当たりの \\
稼働率)
\end{tabular} & & & & & 稼働率 & & & & \\
\hline \multirow[b]{3}{*}{$\begin{array}{l}\text { 施設配 } \\
\text { 置 }\end{array}$} & \begin{tabular}{|l} 
利用者層 \\
の偏り
\end{tabular} & & $\begin{array}{l}\text { サービス圏 } \\
\text { 域人口 }\end{array}$ & & \begin{tabular}{|l} 
I 地域限定性 \\
(主な利用者が \\
地域住民に限 \\
られているか) \\
\end{tabular} & $\begin{array}{l}\text { 利用者がー部 } \\
\text { 地域や団体等 } \\
\text { に集中してい } \\
\text { ないか } \\
\end{array}$ & & & $\begin{array}{l}\text { 利用者が特定地 } \\
\text { 域に偏っていな } \\
\text { いか }\end{array}$ & & & \\
\hline & \begin{tabular}{|l} 
土地利用 \\
状況
\end{tabular} & & \begin{tabular}{|l|} 
圏域の土地 \\
利用状況
\end{tabular} & & & & & & & & & \\
\hline & $\begin{array}{l}\text { 類似施設 } \\
\text { 間バラン } \\
\text { ス }\end{array}$ & & $\mid$\begin{tabular}{|l|} 
施設配置の \\
あり方
\end{tabular} & 隣接状 & 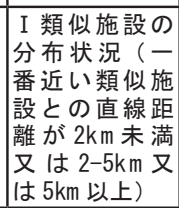 & \begin{tabular}{|l|} 
\\
配置バランス \\
(利用機会の \\
平等)、機能 \\
重複
\end{tabular} & & & \begin{tabular}{|l} 
重複·類似機能 \\
による補完·代 \\
替可能性の有無、 \\
市が直接管理す \\
ることで類似施 \\
設との圽がが保 \\
たれているか
\end{tabular} & & $\begin{array}{l}\text { 類似施 } \\
\text { 設の有 } \\
\text { 無 }\end{array}$ & \\
\hline その他 & & $\begin{array}{l}\text { C02 排出量、文 } \\
\text { 化財的価値、歴 } \\
\text { 史的価値 }\end{array}$ & & & $\begin{array}{l}\text { I 維持管理に } \\
\text { おける市民参 } \\
\text { 画 }\end{array}$ & \begin{tabular}{|l|} 
使用料の適切 \\
\end{tabular} & \begin{tabular}{|l|} 
高度情報化対 \\
空
\end{tabular} & & & & 認知度 & $\begin{array}{l}\text { 他のサービ } \\
\text { スや産業振 } \\
\text { 興に不可欠 }\end{array}$ \\
\hline
\end{tabular}

のバランスを算出する式を示す。

そして再編方針 2（図 6) にある更新の優先度を考慮して学校と その他施設に分けて削減目標值を按分した。再編方針 2 では子育て 重視のため、既存小学校区を維持するとしている。これに基づいて 学校とその他施設を分けて扱う点が秦野方式の特徵である。この結 果、今後 40 年間の削減目標值は学校 $26.2 \%$ 、その他施設 $43.2 \%$ 、 全体で $31.3 \%$ となった。削減目標量が前述の試算よりもやや増えた
理由として、更新優先度の高い子育て支援施設等は他施設より管理 運営費が高いため、この分を多く見込んでおく必要があるからとし ている。

なお、この試算は現在の管理運営費が今後も減額されないという 仮定のもとに成立する。つまり人口や税収減少による管理運営費の 減額を考慮していない。そのため更新施設での管理運営費の削減努 力が必須条件としている。 
2) 玉名市 (図 9)

玉名市の削減目標量設定方法は大きく三項目にわかれる。まず第 一の改善項目で施設の長寿命化と維持管理コストの見直しによる改 善効果の試算、第二の改善項目で施設の複合化・集約化による削減 効果の試算、そして第三の改善項目で市の将来人口推計と公共施設 施設の延床面積の全国平均值から適正規模を算定し、さらに先の施 設複合化・集約化、運営面の効率化効果を勘案し、今後 40 年間で $37 \%$ の削減目標としている。

玉名市の方法は長寿命化、維持管理コスト見直し、複合化、集約 化など現在一般的に考えられている施設効率化手法が網羅的に取り 込まれている点で評価されるがいくつか課題もある。特に改善項目 (3)では、結局、将来人口推計值に住民一人当たりの公共施設の延床 面積の全国平均値（3. $42 \mathrm{~m}^{2} /$ 人） ${ }^{41)}$ を乗じて目標とする施設総量 を試算しており、現況から試算された(1)(2)の結果が目標值設定に反 映されていない。また公共施設の延床面積の全国平均值は指標の一 つに過ぎず、その適正度が担保された值ではないため、当該市に適 用寸る妥当性についても疑問が残る。

\section{3) 先行 2 例の比較考察}

以上 2 例の削減目標值の設定方法を比較する。秦野市では施設更 新不足額と削減施設分の管理運営費削減費用のバランスから更新量 の目安を算出し、再編方針における更新施設優先度を勘案して具 体的な削減目標值を設定している。一方、玉名市では将来人口推計 值に一人当たりの公共施設延床面積の全国平均值を乗じた施設総量 をもとに複合化・集約化、運営効率化等を加味して削減目標值を算 出している。ここで何のための削減目標設定かを考慮すると、それ は将来的に自治体経営上の破綻がないようにという点が最重要であ る。この点からは施設関連コスト面から試算した秦野方式が妥当で ある。そして将来推計人口×単位人口当たりの施設延床面積から 算出される施設総量は参酌值に留めるべきであると考えられる。

\section{6-3. 再配置の地域単位の設定方法}

さらに都市計画的視点から再配置の地域単位の設定方法について 比較する。地区別検討結果を示寸のは表 5 の A5, C2, C3 に分類され た 7 自治体である。そのうち再配置の地域単位を設定しているのは、 秦野市、三豊市、滝川市、宮代町の 4 つで、残る 3 つは地域別に検 討結果を示したのみであった。表 7 に 4 自治体の再配置の地域単位 と施設種別を示す。

まず秦野市の場合、現在の小学校又は中学校敷地を利用した 14 力所の拠点と全市的対応エリアの中央運動公園付近 1 力所を加え た合計 15 カ所のコミュニティ拠点への施設集約をイメージしてい る。但し、地域住民の利用が主となる施設について直線距離で概ね $1 \mathrm{~km}$ を超えての機能移転、機能補完は行わず、 $1 \mathrm{~km}$ 以内に公共施設 がない場合は、開放型自治会館で機能補完するとしている。

次に三豊市では現在の支所周辺、中学校、統合後の小学校等を中 心としてコミュニティ拠点を 7 カ所、全市的なエリアとして総合運 動公園 1 力所の合計 8 力所に集約するイメージを提示している。

そして、滝川市は 5 つの小学校区と 2 つの地区別（うち一つは廃 校になった旧小学校区）に検討し、それぞれの小学校や旧小学校跡 施設に地域施設を集約する。なお滝川市のみが各地区の都市マス タープランにおける地域づくりの目標に言及しており、都市計画政 策との連携がみられる。
40 年後の施設更新量割合 $x(\times 100=\%)$ を求める算定式（※1） (施設更新費不足額と削減施設分の管理運営費削減額をバランス)

(1) 40 年後までの施設更新建設費不足額の年平均 $\mathrm{y} 1$ $\mathrm{y} 1=\alpha / 40 \mathrm{x}-\beta \cdot \cdots(1)$

$\alpha: 40$ 年間の施設更新費の総額（円）

$\beta:$ 施設更新に当てら㚮る予算の年平均額（円 $/$ 年

(2) 40 年後までの施設削減による管理運営費削減額の年平均 $\mathrm{y} 2$ $\mathrm{y} 2=\{\operatorname{ad}(1-\mathrm{x})-(\mathrm{d}-\mathrm{c})(\mathrm{b}-\mathrm{e})\} / 2 \cdots(2)$

a : 40年後までに更新時期を迎える施設の総面積 (m2)

b : 40 年後までに更新時期を迎える学校の総面積 (m2)

c : 学校の管理運営費単価 (円 $/ \mathrm{m} 2)$

$\mathrm{d}$ : 学校以外の施設の管理運営費単価 (円/m2)

e: 40年後の学校の総面積 (m2)

(1) (2)より、y1=y2となる更新割合xを求めると

更新割合 $\mathrm{x}=\{40\{\mathrm{ad}-(\mathrm{d}-\mathrm{c})(\mathrm{b}-\mathrm{e})+2 \beta\} /(40 \mathrm{ad}+2 \alpha)$

(※1) 木造30年、鉄骨造 45 年、RC造60年で建替え、建替え後は 全てRC造 (35万円/坪)。小中学校の建設面積は児童生徒数の減 少を加味して校舎の必要面積を縮小。小中学校の建設は起債 (年 省を加味して校禽の必要面積を縮小。小中学校の建設は起債設年 起債のみ活用。また小中学校の改修は学校建設公社 (年利 $2.0 \%$, 10 年償還) を活用、その他施設の改修は単年度市一般会計による 施行と仮定。

\section{図 8 秦野市の削減目標值算定式の一般化}

\section{現状}

·保有面積 : 32.0 万 $\mathrm{m}^{2}$

. 今後の更新費用平均額 : 43.3億円/年

- 現状の投資的経費 : 8.1 億円 $/$ 年

改善項目(1)長寿命化・維持管理コストの見直し

長寿命化により、建替え時期を建設後60年 770 年に、 大規模改修実施時期を建設後30年 $\rightarrow 35$ 年に変更

$\rightarrow$ 更新費用平均額 35.8 億円 $/$ 年 (約17\%コスト削減)

維持管理コストを事後対応 $\rightarrow$ 予防保全に改善

$\rightarrow$ 約 $20 \%$ コスト削減

(1)により、更新費用平均額 : $43.3 \rightarrow 34.6$ 億円/年に削減可能

改善項目(2)複合化：集約化による削減

約 $20 \%$ 程度の面皘削減を想定

これに伴う運営面の集約化・効率化による削減效果

$\rightarrow 5.6$ 億円 $/$ 年 (約 $13 \%$ コス削減)

(2)により、更新費用平均額： $43.3 \rightarrow 30.5$ 億円/年に削減可能

(1) $+(2)$

・(1)によるコスト削減効果：約 $20 \%$

・(2)によるコス卜削減効果 : 約 $30 \%$

$\rightarrow$ 更新費用平均額 : $43.3 \rightarrow 21.7$ 億円/年に削減可能

改善項目(3)人口減少に伴う保有面積の刿葴と運営面の効果

- H42年の推計人口：約5.9万人

. 公共施設の延床面積の全国平均值3. $42 \mathrm{~m}^{2} / 人$

(対象：981市区町村、東洋大学による（文11）を採用)

$\rightarrow$ 保有面積 : 約 20.1 万 $\mathrm{m}^{2}$ と試算 (H42年)

(この場合、施設更新コスト: 30.2 億円/年、約 $16 \%$ コスト削減)

・さらに施設機能を複合化·集約化、運営面の集約化・効率化 $\rightarrow$ 約 $14 \%$ のコスト削減

(3により、更新費用平均額：21.7 7 15. 2億円/年に削減 (約30\%コスト削減)

\section{削減目標設定}

(1)+(2)+(3)により

更新費用平均額： $43.3 \rightarrow 15.2$ 億円/年に削減可能

$65 \%$ コト削減)

保有面積削減目標：40年間で37\%削減

\section{図 9 玉名市の削減目標量設定の方法}

最後に、宮代町は 3 つの駅周辺に施設群を集約するビジョンを提 示している。具体的には東武東上線の和戸駅、姫宮駅、東武動物公 園駅の 3 駅周辺である。但し、前 2 者は元々の合併前町の中心地区 近くに駅ができたものであり、東武動物公園駅は高度経済成長期以 降に形成された新興住宅街に近い。これらの地区の中心施設に小中 学校等を集約する再配置案を 3 パターン提示している。 
以上 4 例では、地域施設の再配置の中心施設として、小・中学校、 駅、支所、全市的施設の集約先として中央公園等が設定されていた。

なお、小・中学校を地域拠点化する秦野市と駅を中心として拠点 化する宮代町は、ともにその選定理由として既存コミュニティとの 対応性をあげている。つまり、両市とも施設再配置とはいえ、既存 コミュニティの分布状況にも配慮している。また既存施設の評価視 点（表 6）において施設配置カテゴリでは、利用者層の偏り、土地 利用状況、類似施設間配置バランスの小カテゴリが挙げられていた。 利用者層の偏りの項目では利用者が特定地域に偏っていると評価が 低く、類似施設間バランスの項目でも利用機会の平等性や類似施設 との均衡の確保を評価している。つまりこれらの項目では施設利用 機会等が公平であることが評価されている。これらの点からみると、 小学校区は一般的にアクセスの公平性がおおよそ担保され既存コ ミュニティとの対応性もある範域であるため、再編地域単位の基礎 単位の一つとして合理的であると考えられる注6)。

\section{7. 再編計画フローのモデル化}

最後に総務省要請とこれまでの考察結果を交えて再編計画フロー をモデルとして提示する（図 10）。以下の丸数字は表 4 の総務省要 請のカテゴリ番号である。まず(1)既存施設の評価のため、公共性、 建物、コスト、サービス、施設配置に関する情報を揃える。また全 市的な将来人口、税収、更新費用等の見込額を推計する。(2)これら をもとに現状に関する基本的認識、(3)再編に関する実施方針を決定 する。(4)(1)の既存施設情報をもとに施設種別評価を行う。(5)(1)の情 報をもとにサービス水準の検討と削減目標量を設定する。(6)効率化 手法を検討する（PPP 等、今回考察できなかった）。(5)と(6)、さらに は再編地域単位設定を交えて総合的判断を行い再編ビジョンを提示 寸る。以上の計画策定過程において(7)計画手続きの各項目に留意す る。その後の実施計画では期間毎の削減目標量の達成度を評価する。

\section{8. まとめと今後の課題}

本研究では全国の自治体における公共施設の再編計画の策定状況 を把握し、同計画を策定した先行例を抽出して、その構成と検討項 目の策定方法に関する比較考察を行った。結論は以下の通りである。 •まず 2013 年 9 月時点で全国 1, 744 の自治体のうち公共施設の再編 計画を策定済の自治体は $4.0 \%$ とあまり進んでいなかった。

・ 2014 年 4 月に総務省から出された公共施設等総合管理計画策定要 請の項目は、1. 現状と将来に関する認識、2. 公共施設の総合的な 管理実施の方針、3. 検討す心゙き項目や手法、4. 計画手続きの 4 つ に大分類可能であると思われる。

・総務省要請の課題点として、全体の検討手順、行政サービス水準 の評価と検討の方法、そして数值目標の設定方法が明示されていな い、都市計画政策との連関が欠落している、などがある。

・これらの課題点について先行例をもとに比較考察を行った。まず 再編計画の構成内容について、施設種別の再編方針検討結果を提示 するボトムアップ型、全市的検討から削減目標量を明示するトップ ダウン型、両者の統合型の 3 類型により分類した。総務省要請では 削減目標量設定が求められているため、再編計画の理想は統合型と 考えられる。その際、削減目標量と既存施設の現況評価との寸りあ わせ方が重要な課題となると考えられる。
表 7 再配置の地域単位と該当施設

\begin{tabular}{|c|c|c|c|c|}
\hline & 秦野市 & 三豊市 & 滝川市 & 宮代町 \\
\hline \multirow{8}{*}{$\begin{array}{l}\text { 全市 } \\
\text { 的 } \\
\text { 施設 }\end{array}$} & & & 市役所 & \\
\hline & & 総合運動公園 & & \\
\hline & 文化会館 & & 文化施設 & \\
\hline & 図書館 & & & \\
\hline & 総合体育館 & & スポーツ施設 & \\
\hline & 美術館 & & & \\
\hline & 古墳展示館 & & & \\
\hline & & & 病院 & \\
\hline \multirow{14}{*}{$\begin{array}{l}\text { 地域 } \\
\text { 施設 }\end{array}$} & $\begin{array}{l}\text { 再配置単位: } \\
14 \text { 小学校区 }\end{array}$ & $\begin{array}{l}\text { 再配置単位 : } \\
\text { つの支所又は中 } \\
\text { 学校又は小学校 }\end{array}$ & $\begin{array}{l}\text { 再配置単位 : } \\
5 \text { つの小学校と } \\
2 \text { つの地区 }\end{array}$ & $\begin{array}{l}\text { 再配置単位: } \\
3 \text { 駅 (3 地区) }\end{array}$ \\
\hline & & 庁舎·支所 & 消防分団詰所 & \\
\hline & 小学校 & 小学校 & 小学校 & 小学校 \\
\hline & 中学校 & 中学校 & 中学校 & 中学校 \\
\hline & 公民館 & & $\begin{array}{c}\text { 公民館、コミュ } \\
\text { ニティセンター、 } \\
\text { 福祉会館 }\end{array}$ & 公民館 \\
\hline & 児童館 & & 児童館 & $\begin{array}{c}\text { 児童館+ } \\
\text { 老人福祉施設 } \\
\end{array}$ \\
\hline & & & 高齢者福祉施設 & \\
\hline & & & 障害者福祉施設 & \\
\hline & 幼稚園 & & 保育所 & \\
\hline & & & 子育て支援 & \\
\hline & 自治会館 & & & \\
\hline & & & 観光施設 & 郷土資料館 \\
\hline & & 体育館 & & 体育館 \\
\hline & & $\begin{array}{c}\text { ゲートボール場、 } \\
\text { トレーニングセ } \\
\text { ンター等 }\end{array}$ & & \\
\hline
\end{tabular}

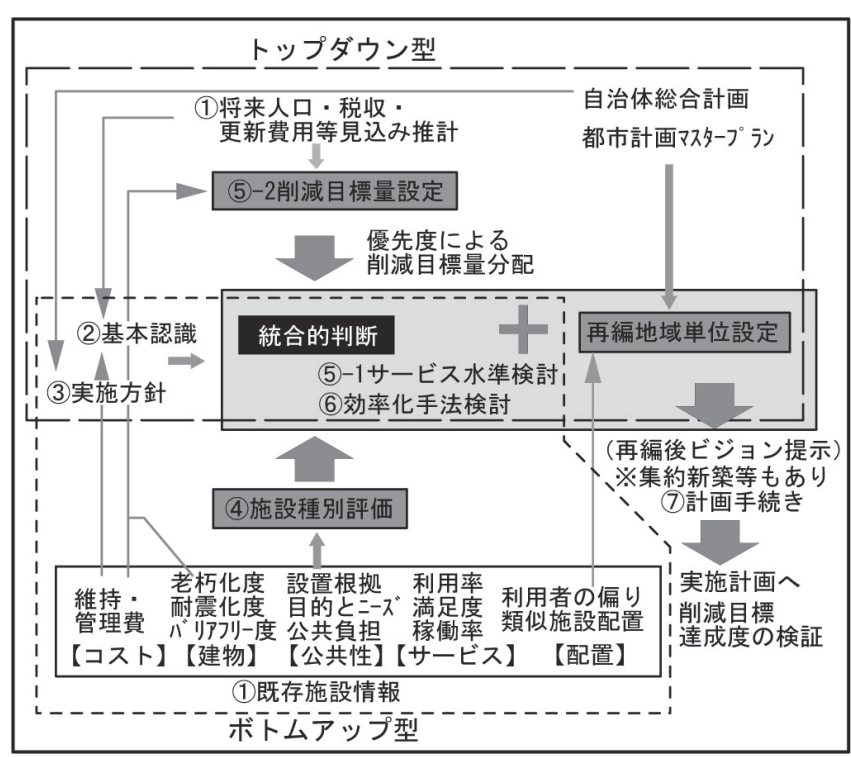

図 10 公共施設再編計画のフローモデル図

・次に行政サービス水準の評価方法について検討した。まず既存施 設の評価視点として、公共性、建物、コスト、サービス、施設配置、 その他の 6 類型がみられた。そして、行政サービス水準の検討に関 寸る評価項目として、利用者数、稼働率等の定量的指標や、利用者 満足度等の定性的指標がみられた。少なくとも定量的指標について の適正水準值の提示は重要な検討課題となる。また設置根拠、設置 目的とニーズの整合性、公共負担の適切性（民間代替可能性）の視 点からの検討により、公共施設数や面積の縮減に直接的につながる 判断が可能になると考えられる。

・そして削減目標量の設定方法として、秦野市では施設更新量と管 理運営費削減のシミュレーションから更新量の目安を算出し、再編 
方針における施設更新優先度を勘案して具体的な削減目標值を設定 している。この方法が先行 2 例中では妥当と考えられた。

・さらに地域施設の再配置の中心施設例としては、小・中学校、駅、 支所があり、全市的施設の集約先例としては中央公園等があった。

・以上をまとめた公共施設の再編計画フローモデル図を提示した。

今後の課題として、行政サービス水準の検討に際しての全国・都 道府県別などを母集団とした利用率や稼働率等、定量的指標の平均 值算出とその適正性に関する考察が挙げられる。また広域連携の具 体的あり方、PPP 等の効率化手法についても考察できなかったので、 課題としたい。

\section{注}

注 1) この節は清水直君の平成 25 年度金沢大学卒業論文「自治体の公共施設 再編計画の手法に関する研究」をもとに加筆修正したものである。

注 2） 47 都道府県すべて、市区町村でも相対的に規模の大きな自治体を中心 に 981 の自治体データによる計算值（文 41）。

注 3）例えば、平成 26 年 8 月施行された改正都市再生法では、都市機能誘導 区域と居住誘導区域老定め、前者を医療施設や福祉施設、商業施設その他 居住に関連する施設の立地を誘導すべき区域としている（文 42）。

注 4）秦野市政策部公共施設再配置推進課による

注 5）例えば、廣田ら（2013）（文 2）は習志野市を対象とした公共施設の供 給量を把握するにあたり、千葉県内で人口密度と一人当たりの公共施設面 積のクロス分析から習志野市と同類に分類された 6 自治体を母数として、 一人当たりの公共施設延床面積等を比較している。つまり、当該県内で類 似傾向をもつ自治体を母集団として比較している。

注 6）小学校が統廃合され、必ずしも空間的アクセスの公平性が担保されな い地域の場合には旧小学校区から検討を始めるとよいと思われる。

\section{参考文献}

1）総務省 HP:http://www. soumu. go. jp/iken/koushinhiyou. html, 2014. 10.20 参照

2）萩原裕晃，廣田直行ほか：習志野市における公共ストックを利用した施設 再編計画，地域施設設計研究論文 31, pp. 17-22,2013.7

3）畑真由香, 廣田直行ほか: コミュニティ施設の複合化による地域拠点形成 について, 地域施設設計研究論文 32, pp. 51-60, 2014.7

4) 伊丹康二, 横田隆司ほか : 大阪市豊中市における公共施設の用途変更の 実態と施設運営上の課題に関する研究, 日本建築学会大会学術講演梗概集 E1, pp. 37-40, 2011. 8

5）長谷部裕子, 友清貴和ほか : 人口減少と市町村合併に伴うコミュニティ 施設再編のための指標抽出その 1, 日本建築学会大会学術講演梗概集 E1, pp. 337-338, 2008. 9

6）友清貴和, 長谷部裕子ほか：人口減少と市町村合併に伴うコミュニティ 施設再編のための指標抽出その 2, 日本建築学会大会学術講演梗概集 E1, pp. 339-340, 2008.9

7）山本康友, 吉田倬郎：日本国内の公共建築のストック量とその地域的な特 徵に関する調查研究, 日本建築学会計画系論文集 No. 587pp. 143-148, 2005.1

8）山下光博, 吉田倬郎, 山本康友 : 庁舎施設一の維持保全投資の実態に関す る研究, 日本建築学会計画系論文集 No. 628, pp. 131-1319, 2008.6

9）李祥淮, 小松幸夫 : 地方自治体公共施設の運営管理状況調查, 日本建築学 会大会学術講演梗概集 E1, pp. 1287-1288, 2008.9

10）山本康友：公共施設の所有量, 所有コストと行政ニーズ, 日本建築学会 大会学術講演梗概集 E-1, pp. 33-36, 2011.8

11）かわさき資産マネジメントカルテく資産マネジメントの第 2 期取組 期間の実施方針＞について, 2014. 3, http://www. city. kawasaki. jp/230/ page/0000056256. html, 2014.12.24 参照

12）さいたま市公共施設マネジメント計画・第 1 次アクションプラ ン , 2014. 3, http://www. city. saitama. jp/006/007/014/014/002/p034900_d/ fil/plan_all.pdf, 2014.12.24参照

13）浜松市公共施設再配置計画 ・ 個別計画, http://www. city. hamamatsu. shizuoka. jp/shisankeiei/asset/kobetsu/index. html, 2014. 12. 24 参照

14）板橋区公共施設等の整備に関するマスタープラン, 2013. 5, http:// www. city. itabashi. tokyo. jp/c_kurashi/053/attached/attach_53825_1. pdf, 2014.12. 24 参照
15）豊中市市有施設有効活用計画，2011. 7, https://www. city. toyonaka. osaka. jp/machi/seibikatuyo/katuyo/keikaku. files/keikaku201107. pdf, 2014. 12. 24 参照

16）寝屋川市公共施設等整備・再編計画（改訂版）, 2014. 2, http://www. city. neyagawa. osaka. jp/ikkrwebBrowse/material/files/ group/10/20140225. pdf. , 2014. 12. 24 参照

17）第 3 次点市公共施設再配置計画・コミュニティ施設再配置基本方 針, 2014. 8, http://www. city. kure. lg. jp/kureinfo/gyousei140911_0102. pdf, 2014. 12.24 参照

18）上越市公の施設の再配置計画, 2011. 10, http://www. city. joetsu. niigata. jp/uploaded/attachment/50205. pdf, 2014. 12.24 参照

19）西東京市公共施設の適正配置等を推進するための実行計画（2012 2016) , http://www. city. nishitokyo. lg. jp/siseizyoho/sesaku_keikaku/ kokyo_tekisei/jikkoukeikaku. html, 2014. 12.24 参照

20）秦野市公共施設再配置計画 , 2011. 3

21）習志野市公共施設再生計画, 2014. 3, https://www. city. narashino. 1g. jp/ matidukurisanka/koukyou_saisei/saiseikeikaku/180120140428143647879. html, 2014. 12.24 参照

22）稲沢市公共施設再編に関する考え方〜 20 年先の未来のために, 2013. 6, http://www. city. inazawa. aichi. jp/ka_annai/kikaku/arikata/ kangaekata. pdf, 2014. 12.24 参照

23）飯塚市公共施設等のあり方に関する第二次実施計画, http://www. city. iizuka. 1g. jp/06machi/gyozaisei/public/plan. pdf, 2014. 12. 24 参照

24）長浜市公共施設有効活用計画, 2011. 4, http://www. city. nagahama. shiga. jp/index. cfm/6, 22255, c, html/22255/20120507-112808. pdf, 2014. 12. 24 参

25）白山市公共施設の統廃合及び管理見直し方針, http://www. city. hakusan. ishikawa. jp/data/open/cnt/3/7247/1/minaoshihoushin. pdf, 2014. 12. 24 参

26）鎌ケ谷市公共施設再編計画 , 2009. 2, http://www. city. kamagaya. chiba. jp/sesaku/shisetsusaihen/saihenkeikaku. pdf, 2014. 12. 24 参照

27）ふじ夕野市公共施設再配置計画, 2010.9, http://www. city. fujimino. saitama. jp/doc/2014110600577/file_contents/all.pdf, 2014. 12.24 参照

28）坂井市公共施設マネジメント白書, 2012.3, http://www. city. fukuisakai. lg. jp/shisei/05/p003990. htm1, 2014.12.24 参照

29）北名古屋市公共施設管理運営の見直し計画, 2012. 3, http://www. city. kitanagoya. 1g. jp/keiei/files/upload/files/1800055_01.pdf, 2014.12.24 参

30）狛江市公共施設整備計画, 2012. 11, http://www. city. komae. tokyo. jp/index. cfm/36, 31437, c, html/31437/koukyoushisetuseibikeikaku. pdf, 2014. 12.24 参照

31）玉名市公共施設適正配置計画 , 2013. 3, http://www. city. tamana. 1g. jp/ data/open/cnt/3/4755/1/keikakusyo_zenpen.pdf, 2014. 12. 24 参照

32）三豊市公共施設再配置計画（第 1 期基本計画）, 2013. 6, http://ww city. mitoyo. 1g. jp/div/zaisei/pdf/01_keikaku. pdf, 2014. 12. 24 参照

33）清須市公共施設のあり方の基本方針, 2010.2, http://www. city. kiyosu. aichi.jp/shisei_joho/keikaku_shisaku/kobetsu_bunyabetsu_keikaku/ sonota/kokyo_shisetsu_kihon_hoshin. files/zentai.pdf, 2014.12.24 参照

34）京丹後市公共施設見直し計画 2013. 5, https://www. city. kyotango. lg. jp/shisei/sanka/public/h24/koukyouminaoshi/kekka/documents/ bessi2. pdf, 2014. 12. 24 参照

35）南砺市公共施設再編計画, 2011.3, http://www. city. nanto. toyama. jp/ cms-sypher/open_imgs/info/0000000093_0000029163.pdf, 2014.12.24 参照

36）滝川市公共施設マネジメント計画 2013 ～2022, 2014. 2, http://www. city. takikawa. hokkaido. jp/200soumubu/06stock_management/files/ keikaku. pdf, 2014. 12.24 参照

37）宮代町公共施設マネージメント計画 , 2011. 11

38）対馬市第 2 次公共施設見直し実施計画, 2012.3, http://www. city. tsushima. nagasaki.jp/policy/images/keikaku/h2403_koukyo. pdf, 2014. 12. 24 参照

39）美馬市公共施設の再編整備に関する基本方針, 2011. 3, http://www. city. mima. 1g. jp/dbps_data/_material_/localhost/kihonnhousinn1. pdf, 2014. 12.24 参照

40）能勢町公の施設等のあり方検討（報告書）,2007. 8, http://www. town. nose. osaka.jp/dbps_data/_material_/localhost/pdf/ ooyakesaisixyuu_2401.pdf, 2014.12.24参照

41）東洋大学：自治体別人口・公共施設延床面積リス卜, http：//www. toyo. ac. jp/site/pppc/30712. html, 2014. 12. 24 参照

42）国土交通省 HP:http://www. mlit. go. jp/kisha/kisha07/04/040205_. html, 2014. 8.29 参照 


\title{
DISCUSSION OF STRUCTURE AND CONTENT OF EARLY ADOPTING MUNICIPALITIES’ PUBLIC FACILITY REORGANIZATION PLANS
}

\author{
Tatsuya NISHINO* \\ * Assoc. Prof., School of Environmental Design, College of Science and Engineering, Kanazawa University, Dr. Eng.
}

\section{Introduction}

The reorganization, including substantial reduction, of public facilities owned by Japan's municipalities is becoming a major issue. The purpose of this study is to understand the state of the establishment of public facility reorganization plans by municipalities nationwide, extract precedent examples of reorganization plans already established, and compare and discuss their structures and the criteria used to formulate the plans.

\section{Research Method}

The objects of this study were public facility reorganization plans created by 1,744 municipalities nationwide (as of September 2013). The method of investigation was gathering documents and materials. Materials related to reorganization policies and reorganization plans of public facilities were downloaded from the websites of municipalities.

\section{Discussion}

First, of the 1,744 municipalities nationwide, only 4.0 percent have completed formulation of a public facility reorganization plan. Thus, there has not been much progress in the establishment of public facility reorganization plans.

In April 2014, the Ministry of Internal Affairs and Communications (MIC) requested municipalities to formulate a "Comprehensive Management of Public Facilities and Infrastructure Plan.” The items requested by MIC of municipalities can be broadly placed into the following four categories: (1) gain awareness of present and future state of facilities, 2) establish policy for actual implementation of comprehensive management of public facilities, 3) find items and methods that should be studied, and 4) establish steps to carry out the plan.

Issues of contention in MIC's request include the absence of explicit specifications concerning the overall review procedure, methods for evaluating and examining levels of local facility services, and methods for setting numerical targets. There was also a lack of connection between the request items and the establishment of urban planning policy.

We compared precedent examples of reorganization plans on the basis of these problem points.

First, concerning the structure and content of the reorganization plans, we were able to divide them into three types: bottom-up (the reorganization policy is studied by facility type); top-down (the reduction target amount is established by a city-wide review); and integratedtype of two styles. However, because of the conditions by which we extracted precedent cases, the top-down type could not be observed. Because MIC's request asked for a reduction target amount to be set, we believe the ideal reorganization plan is the integrated-type. How to reconcile the reduction target amount and the evaluation of the existing facilities' conditions then becomes a critical challenge.

Next, we examined methods for evaluating the level of facility services. First, six criteria could be discerned for evaluating an existing facility: its public nature, physical buildings, costs, services, location, and others. For evaluation of the level of facility services, the number of users and utilization rate were observed as quantitative indicators; needs by residents, satisfaction of users, and level of contribution to the city's facilities were observed as qualitative indicators. Also, from reviewing the basis for the facility's establishment, the consistency between this purpose and the needs of the residents, and its appropriateness as a public burden, decisions about the number of public facilities and the reduction in the facilities' total floor space become possible.

As a method to set the reduction target amount, Hadano City is establishing a specific target by calculating an estimate using simulations of the updated amount of facilities and the reduction in management and operating costs, and by taking into account priority facility updates in its reorganization plan. We believe this method is appropriate for two of the precedent examples.

Primary examples of community facilities that are relocated include elementary and junior high schools, train stations, and municipal government branch offices. Examples of consolidated city-wide facilities include central parks. 